\title{
ESTIMATION OF PRODUCTIVITY AND PRIME COST OF LOGSET 5HP GT HARVESTER IN THINNING
}

Guna PETAJA, Latvian State Forest Research Institute "Silava”, Rigas street 111, LV-2169, Salaspils, Latvia; guna.petaja@,silava.lv (corresponding author)

Aldis BUTLERS, Latvian State forest research institute "Silava"; Rigas street 111, LV-2169, Salaspils, Latvia; aldis.butlers@,silava.lv Modris OKMANIS, Latvian State forest research institute "Silava"; Rigas street 111, LV-2169, Salaspils, Latvia; modris.okmanis@silava.lv

Agris ZIMELIS, Latvian State forest research institute "Silava”; Rigas street 111, LV-2169, Salaspils, Latvia; agris.zimelis@,silava.lv

Productivity of a harvester significantly affects costs of mechanized felling, which in turn determines, if commercial thinning will be profitable. The objective of this study is to estimate productivity and prime cost of Logset 5HP GT harvester with increased boom length (11 m), equipped with the TH45 felling head, in thinning. Trials are conducted in Latvia, eastern Vidzeme, in coniferous stands. To evaluate productivity of Logset 5HP GT, a time study was carried out. Influence of small trees (diameter at breast height $<8 \mathrm{~cm}$ ) on productivity and harvesting cost was also determined. During the trials 2379 trees are harvested with the total stem volume of 400 $\mathrm{m}^{3}$. The diameter at breast height of an average harvested tree is $14 \mathrm{~cm}$ and volume of a stem $-0.171 \mathrm{~m}^{3}$. Duration of time study is $33.5 \mathrm{~h}$. Obtained productivity rates of Logset 5HP GT are compared with those of John Deere $1070 \mathrm{D}$ harvester. According to the study results average productivity of Logset 5HP GT harvester in thinning of coniferous stands is $13.85 \mathrm{~m}^{3}$ per productive work hour. Prime cost of harvesting of the Logset 5HP GT in thinning is $8.02 € \mathrm{~m}^{-3}$. Increased boom length allows to decrease the total time spent for driving in a stand by $71 \%$. Harvesting of small trees reduces productivity by $6.9 \%$ and increase production cost by $2.1 \%$ in the experimental stands. Difference between productivity of Logset 5HP GT and John Deere 1070 D in similar conditions is statistically insignificant.

Keywords: harvester, harvesting productivity, Logset $5 H P$ GT, thinning

\section{INTRODUCTION}

Commercial thinning allows to generate income from sales of extracted timber, increase timber yield per hectare and maximize income from final felling. About $20 \%$ of the annually produced logs in Latvia are obtained from thinnings (Petersons, 2010). Thinnings in Nordic countries are mostly mechanized, e.g., in Finland harvesters are used in $90 \%$ of thinnings (Kärhä et al., 2004, Mederski, 2006, Moskalik et al., 2017). In order to predict economic feasibility of a mechanized thinning, it is important to precisely estimate productivity of harvester, harvesting cost and revenue from selling timber. Although use of harvesters in thinnings has a significant impact on productivity of logging, the potential of mechanized thinning has not been used to full extent, particularly in early thinning in Latvia due to its complexity and economic challenges related to investments and operating costs.

Harvester productivity is influenced by forest stand density, average stem volume, species composition, soil condition, tree arrangement, stem shape, thinning intensity, thinning method, arrangement of strip roads, slope gradient and terrain configuration (Eliasson, Lageson, 1999; Stampfer, 1999). There is a presumption that under similar conditions productivity indicators of harvester are better in coniferous stands than in deciduous or mixed stands (Kuitto et.al., 1994). Cut-to-lenght method is the most suitable for commercial thinnings, because it requires less space in the stand to place timber, is environmentally friendlier and causes less damage to timber during haulage. Productivity increases along with tree dimensions, but starts to decrease, when the optimal tree dimensions for the harvester are exceeded (Nurminen et al., 2006). The average productivity of mechanized logging in the first thinning in coniferous stands is within a range of 30 $50 \mathrm{~m}^{3}$ per shift of 8-10 hours, in commercial thinning-50-100 $\mathrm{m}^{3}$ per shift, but in final felling $-120-220 \mathrm{~m}^{3}$ per shift. Felling and stem processing takes about 20-60 s, depending on tree dimensions. The average time distribution for preparing logs in final felling is as follows: positioning the harvester head and felling a tree (30\%), delimbing and crosscutting (45\%), driving (10\%), other activities (15\%). In thinnings the time proportion required for driving in the stand is increasing, but time required for delimbing - decreasing (Uusitalo, 2010).

Three the most commonly used harvesters in Latvia are John Deere 1070, Ponsse Beaver and Valmet 901.4 (Pētersons, Drēska, 2014). A current problem with those harvesters is difficulty to reach and hold trees that are growing

Copyright (C) 2017 The Authors. Published by Aleksandras Stulginskis University. This is an open-access article distributed under the terms of the Creative Commons Attribution License (CC-BY 4.0), which permits unrestricted use, distribution, and reproduction in any medium, provided the original author and source are credited. 
in 8-10 m distance from the center of the strip road during felling. In order to ensure optimal and even arrangement of remaining trees after thinning, harvester has to drive off the strip road in herringbone pattern. This working method negatively influences productivity as well as increases tree and soil damages. An alternative solution is to use a bigger harvester in thinnings (John Deere 1270, Ponsse Ergo or similar). It would increase productivity and quality of thinning, as well as production costs due to larger investments, fuel consumption and maintenance costs. The main drawback of large forestry machines in thinning is their weight, which hinders their use on soils with low bearing capacity.

Mechanized thinning is economic challenge, because operation costs of the harvester remain the same regardless of dimensions of felled trees, while diameter of extracted trees play an important role in logging productivity and timber value (Belbo et al., 2010). In order to reduce costs, it is possible to use other alternatives instead of harvesters. In a study conducted in Finland assessment of productivity of an agricultural tractor $150 \mathrm{hp} \mathrm{Valmet} \mathrm{XM,} \mathrm{equipped} \mathrm{with} \mathrm{a} 9 \mathrm{~m}$ Cranab FC 80 forwarder crane and felling head Nisula 280E, in thinning was carried out. However it was found that productivity is significantly lower comparing with results of other studies under similar conditions, when harvester was used in logging, therefore logging wasn't economically feasible. Differences can be explained with the fact that harvesters are constructed specifically for forest operations and are more stable and ensure better working conditions for the operator (Belbo et al., 2010). Promising results were achieved with small-class Vimek $404 \mathrm{~T} 5$ harvester in Sweden $\left(5.3 \mathrm{~m}^{3} \mathrm{~h}^{-1}\right.$ in pre-commercial thinning and considerably smaller prime cost forecast in comparison to middle-class harvesters due to smaller operational cost within the same productivity range), however this machine is specialized for pre-commercial thinning will not work efficiently in late thinnings and final felling (Lazdinš̌ et al., 2017).

Acquisition of a harvester is a significant investment, therefore prediction of financial flow depends on the assessment of economic life of the machine, annual exploitation and the end value. The chosen method of technological process also has impact on costs of mechanized logging operations. A research on productivity and costs of harvester in thinnings in pine stands, when distance between strip roads is either 35-38 m (trees that could not be reached with a harvester were felled with a chainsaw in the direction of strip road) or 18-20 m, was conducted in Poland. It was found that productivity of the Timberjack 770 harvester in the 44 -year-old stand is $5.9 \mathrm{~m}^{3} \mathrm{~h}^{-1}$ and $4.5 \mathrm{~m}^{3} \mathrm{~h}^{-1}$ and in the 72 -yearold stand $-11.5 \mathrm{~m}^{3} \mathrm{~h}^{-1}$ and $8.7 \mathrm{~m}^{3} \mathrm{~h}^{-1}$, respectively. Logging cost in the younger stand was $5.78 € \mathrm{~m}^{-3}$, when distance between strip roads is $35-38 \mathrm{~m}$ and $6.72 € \mathrm{~m}^{-3}$, when distance between strip roads is $18-20 \mathrm{~m}$. Logging cost in the older stand was $5.58 € \mathrm{~m}^{-3}$ and $6.78 € \mathrm{~m}^{-3}$, accordingly. Costs are lower, when strip roads are less dense due to higher productivity and lower fuel consumption (Mederski, 2006).

The aim of this study was to assess productivity and harvesting cost of Logset 5HP GT harvester, equipped with TH45 felling head and crane with increased boom length, in forest thinning.

\section{MATERIALS AND METHODS}

Trials were conducted in eastern Vidzeme from 14.07.2015. till 24.07.2015. Most of felling sites were located on mineral soils that are classified as dry, soil bearing capacity was sufficient and terrain was flat. The average daily temperature was $16.8{ }^{\circ} \mathrm{C}$. Sky was clear or slightly cloudy. There was rain only one day during trials and one day during the week before trials, therefore soil conditions remained stable and dry. There was no strong wind during trials.

Harvesting was done with Logset 5HP GT harvester. Specifications of the harvester are provided in table 1. Harvester was equipped with ECO-Baltic tracks on front axle. During trials tires were filled with salt solution to ensure stability (in each front tire $-150 \mathrm{~kg}$, in each rear tire $-300 \mathrm{~kg}$ ).

Table 1. Logset 5HP GT harvester specification

\begin{tabular}{|c|c|}
\hline Parameter & Value \\
\hline Dimensions & weight -15 tonnes, width $-2.5 \mathrm{~m}$, length $-7.2 \mathrm{~m}$ \\
\hline Engine & $\begin{array}{l}\text { Sisu } 74 \mathrm{AWI} \text {, power } 150 \mathrm{~kW} \text {, torque } 1000 \mathrm{Nm} \text {, fuel tank } 520 \mathrm{~L} \text {, fuel consumption - 9- } \\
12 \mathrm{~L} \text { per hour }\end{array}$ \\
\hline Transmission & hydrostatic mechanical, tractive effort $135 \mathrm{kN}$ gearbox -2 gears \\
\hline Hydraulic system & oil tank $200 \mathrm{~L}$, oil flow $190 \mathrm{~L} \mathrm{~min}^{-1}$ \\
\hline Crane & $\begin{array}{l}\text { Mesera-Loglift L220V, crane reach } 11 \mathrm{~m} \text {, lifting capacity } \\
\qquad 188 \mathrm{kNm}\end{array}$ \\
\hline Tyres & front $-600 / 50-22.5$, rear $-600 / 65-34$ \\
\hline Harvester head options & TH45, TH55, TH65 \\
\hline Measuring system & TOC-MD \\
\hline
\end{tabular}

During the trials Logset 5HP GT harvester was equipped with the TH45 felling head. TH45 is the smallest from Logset standard felling heads and is designed for biofuel preparation in thinnings with relatively small size trees. Specification of TH45 felling head is given in table 2.

Productivity values of Logset 5HP GT harvester was compared with those of John Deere 1070 D obtained in similar conditions. Impact of boom length on productivity was estimated by comparison of time spent for driving in stands 
of both harvesters. In trials with John Deere 1070 D H754 harvester head was installed, boom length was $10 \mathrm{~m}$, engine power $-136 \mathrm{~kW}$, harvester length $-6.75 \mathrm{~m}$, width $2.62 \mathrm{~m}$, own weight -14.1 tonnes.

Table 2. TH45 harvester head specification

\begin{tabular}{|c|c|}
\hline Parameter & Value \\
\hline Width, head open, mm & 1250 \\
\hline Width, head closed, mm & 1110 \\
\hline Height with rotator and link, $\mathrm{mm}$ & 1700 \\
\hline Weight with rotator and link, $\mathrm{kg}$ & 850 \\
\hline Max. cutting diameter, $\mathrm{mm}$ & 550 \\
\hline Saw bar lenght, mm & 640 \\
\hline Saw type & SuperCut \\
\hline Saw engine & Parker/Bucher \\
\hline Saw oil tank volume, $\mathrm{L}$ & 8 \\
\hline Maximum pressure, bar & 280 \\
\hline Optimum oil flow, $\mathrm{L} \mathrm{min}^{-1}$ & 160 \\
\hline Hydromotors of feed rollers, $\mathrm{cm}^{3}$ & $400 / 500$ \\
\hline Number of hydraulic motors, pes & 2 \\
\hline Feed rate, $\mathrm{m} \mathrm{s}^{-1}$ & $6.0 / 4.7\left(240 \mathrm{~L} \mathrm{~min}^{-1}\right)$ \\
\hline Maximum delimbing diameter, $\mathrm{mm}$ & 400 \\
\hline Delimbing knives, pcs & 1 fixed, 3 movable \\
\hline Maximum tilting angle of a harvester head, degrees & 140 \\
\hline Recommended weight of the base machine, tonnes & $\begin{array}{l}\text { 14-20 for wheeled and } 15-21 \text { for tracked } \\
\text { machines }\end{array}$ \\
\hline Additional equipment & $\begin{array}{l}\text { Timber coloring, stump treatment with } \\
\text { urea or Rotstop, additional grips for } \\
\text { packaging small roundwood, diameter } \\
\text { measuring system }\end{array}$ \\
\hline
\end{tabular}

Cut-to-length working method was used - firstly a strip road was cleaned, afterwards trees along both sides of the strip road were felled. Logs were placed placed alongside strip roads under 45-90 degrees angle. Logging residues were placed in strip roads, where necessary to improve forwarding conditions, or left in a stand. Accumulating function of harvester head was used in certain cases, however it is not commonly used in Latvia due to quality requirements for pulpwood and firewood assortments (Kalēja et al., 2014). Undergrowth trees were cut by chainsaws before logging. Small trees were cut down mainly in order to open space for placing logs. Diameter of felled trees was measured using the measuring function of the felling head. Notes were taken about species of each felled tree.

Productivity of the working method was analyzed on a base of data where each work cycle represents processing of single tree. Time study was carried out according to the planned working day of the operator, separating the productive work time (planned working time when engine is running except idles longer than 15 min) from effective work time, which includes only log preparation operations. Time consumption was studied for each operation of timber processing separately and there were 14 operations in total (Table 3). Productive work time was used to characterize harvester's productivity, which includes timber preparation, driving into and out of stand and short breaks (up to 15 min), while engine of harvester is still running. Time studies of harvesting were carried out during daytime, 8-10 hours per day, using a field PC Allegro CX, equipped with time accounting software SDI. Data about the productivity of harvester was expressed as the volume of processed logs in cubic meters per time unit - productive work hour $\left(\mathrm{m}^{3} \mathrm{~h}^{-1}\right)$.

Prime cost and revenue were calculated with a model, which is based on FLIS model that is developed in Swedish forestry institute Skogforsk. The new model is developed in LibreOffice application by LSFRI Silava staff, using data from previous studies carried out in Latvia (Lazdiņš et al., 2015; von Hofsten et al., 2005). Timber processing and transportation system (harvester, forwarder and log truck) expenditures are included in calculation of logging costs. Price of the harvester $355000 €$ and price of the felling head $52000 €$ were used in calculations. The price of John Deere 810 forwarder, log truck and other timber transportation related costs and their productivity indicators were taken from a study about usage of Moipu harvester head (Lazdinš et al., 2015). The average road transport distance was assumed as $40 \mathrm{~km}$, the average hauling distance $-0.3 \mathrm{~km}$. Working hours of harvester's engine were assessed according to data from the company which carried out logging. Personnel costs were calculated, assuming that 2 operators are working in 2 shifts each working day, duration of the shift is $8 \mathrm{~h}$. It was assumed that there are 260 working days a year and technical readiness of the harvester constitutes $85 \%$ of planned working time. The average hourly rate is $7 € \mathrm{~h}^{-1}$, excluding 
employers' social tax, per day payments, compensation for travel to work, insurance and periodic training, which were added separately (Lazdiņš et al., 2015). Driving from one felling site to another was excluded from work time. The average fuel consumption in trial objects was $11.78 \mathrm{~L}$ per engine hour. Log prices

Table 3. Work operations in productivity studies

\begin{tabular}{|c|c|c|}
\hline Work time category & Operation & Explanation \\
\hline \multirow[t]{13}{*}{ Productive time } & Reach & Reach for a tree \\
\hline & Grip & Grip the tree \\
\hline & Cut & Cut the tree \\
\hline & Pull & Pull stem \\
\hline & Delimb & Delimbing and cross-cutting a stem \\
\hline & Branches & $\begin{array}{c}\text { Operations with branches, excluding putting logging residues } \\
\text { into strip road }\end{array}$ \\
\hline & Strip road & Putting logging residues into strip roads \\
\hline & Drive & Moving in the stand \\
\hline & Undergrowth & Clearing undergrowth \\
\hline & Drive in & Time consumed by driving into the stand \\
\hline & Drive out & Time consumed by driving out from the stand \\
\hline & Other & Other work-related operations (small repairs and service, etc.) \\
\hline & Stop & Operations unrelated to work, engine is running (up to $15 \mathrm{~min}$ ) \\
\hline Unproductive time & Empty & Breaks longer than 15 min when engine is running or stifled \\
\hline
\end{tabular}

were assumed according to data from the Central Bureau of Statistics on average timber prices in 2016.

Data were processed with software LibreOffice Calc. Statistical analysis was carried out with R software package. In order to test if obtained data follow the normal distribution Shapiro-Wilk normality test was used, Mann-Whitney U test was used to compare average values of two independent sample groups, but Wilcoxon signed rank test was used for paired sample groups.

\section{RESULTS AND DISCUSSION}

During trials 2379 trees with the total stem volume of $399 \mathrm{~m}^{3}$ over bark were extracted. The breast height diameter of an average felled tree was $14 \mathrm{~cm}$, height $-13 \mathrm{~m}$, and stem volume over bark $-0.17 \mathrm{~m}^{3}\left(0.15 \mathrm{~m}^{3}\right.$ under bark). Due to the small number of extracted deciduous trees (48 stems), productivity of harvesting was not calculated for deciduous trees separately, but data were included in calculation of the average productivity of the harvester for both machines. Mostly small dimension trees $\left(\mathrm{D}_{1.3}<10 \mathrm{~cm}\right)$ were extracted, however, stem volume proportion of larger trees is significant and it influenced productivity indicators of harvester in thinning. In trials $87 \%$ of the total time consumed was productive working time, from which the proportion of effective working cycles resulting with production of logs was $96 \%$. When processing trunk, most of time was consumed for stem delimbing and bucking ( $45 \%$ of effective working time). $9 \%$ of effective working time constituted driving in the felling site, $11 \%$ - boom positioning and reaching for the trees and $12 \%$ - pulling a felled stem. According to the average productivity values in trials, when the diameter of extracted trees is 14 $\mathrm{cm}$, harvester can produce about 33 thousand $\mathrm{m}^{3}$ of logs per year.

During evaluation of correlation between the amount of prepared logs and time consumption, it was found that more time was consumed for processing smaller trees, which make a comparatively small contribution to the total volume of produced logs. Working time for production of $1 \mathrm{~m}^{3}$ of logs decreased, if diameter of extracted trees increased. The increasing proportion of logs produced from larger trees indicates a significant increase of productivity along with increasing diameter of extracted trees. When diameter of extracted trees ranges from $4 \mathrm{~cm}$ to $35 \mathrm{~cm}$, productivity of harvester increases accordingly from 0.5 to $60.8 \mathrm{~m}^{3} \mathrm{~h}^{-1}$, whereas, the count of processed trees per time unit decreases along with increasing tree dimensions. When tree diameter reaches $36 \mathrm{~cm}$, there is a rapid decrease in productivity of the harvester. It can be explained with unsuitableness of the harvester and the felling head to extraction of large tree in final felling. However these data may not be representative because the proportion of large trees was small. When the average stem volume of processed trees reaches $0.6 \mathrm{~m}^{3}$, productivity of the harvester is $35 \mathrm{~m}^{3} \mathrm{~h}^{-1}$. Decrease in productivity when processing trees with stem volume above $0.6 \mathrm{~m}^{3}$ indicates that the felling head is not suitable for processing of large trees.

The trials demonstrated that Logset 5HP harvester can process up to 140 small trees per hour, but the amount of processed trees per time unit decrease along with increasing tree dimensions. The proportion of small trees $\left(D_{1.3}<8 \mathrm{~cm}\right)$ in thinning was $18 \%$ and the proportion of their stem volume was $2 \%$. The average productivity of processing of the small size trees was $2.3 \mathrm{~m}^{3}$ or 113 trees per productive work hour. Using data from time studies, a theoretical estimation of productivity for additional working methods has been made: 1) small trees are felled on strip roads (20\% of small trees), but not processed; 2) small trees are extracted in the whole stand, but logs are not produced. Obtained results were 
compared with productivity values of the work method used in the trials. Average productivity in the trials was $13.85 \mathrm{~m}^{3}$ per productive work hour, but when working methods 1 and 2 were applied, the expected productivity would increase to $14.8 \mathrm{~m}^{3}$ and $14.5 \mathrm{~m}^{3}$ per productive work hour, accordingly. The increase of productivity would be $6.9 \%$ and $4.7 \%$, accordingly. With a $95 \%$ credibility there is a statistically significant difference between estimated productivity values of different work methods $(\mathrm{p}<0.050)$. It must be taken into consideration that influence of changing work conditions due to application of different harvesting method on productivity is not assessed.

A significant influence of species on harvester productivity was not observed $(p=0.1048)$. The amount of processed pine trees and spruce stems was similar $-191 \mathrm{~m}^{3}$ and $199 \mathrm{~m}^{3}$, accordingly. The productivity by the tree diameter groups and distribution of work time consumed was similar for all operations. A significant influence of the tree species on time consumption for processing one of singe tree was not observed $(\mathrm{p}=0.8918)$. Depending on stem diameter class, processing 1 spruce took 0.34-1.32 min, whereas processing 1 pine took 0.31-1.49 min. The average productivity of processing spruces was $10 \mathrm{~m}^{3}$ per productive work hour, whereas, productivity of processing of pines was $24 \mathrm{~m}^{3}$ per productive work hour. Differences in average productivity is result of difference of dimensions of the processed trees - the average diameter and stem volume of extracted spruces growing mainly in second floor are smaller than those of a pines. There were no differences in productivity, when processing trees with a diameter of $17 \mathrm{~cm}$ or smaller. When the diameter exceeded 17 $\mathrm{cm}$, productivity was slightly higher, when processing spruces, however, differences are not statistically significant $(\mathrm{p}=0.0759)$. Depending from the tree diameter $(4-33 \mathrm{~cm})$ productivity of spruce harvesting was $0.53-52.16 \mathrm{~m}^{3}$ per productive work hour. In pine stands (diameter of extracted trees 8 to $35 \mathrm{~cm}$ ) productivity of the harvester ranged from 4.09 to $60.84 \mathrm{~m}^{3}$ per productive work hour.

Productivity rates and work time distribution of Logset 5HP GT harvester were compared with those of John Deere 1070 D harvester. Work method in trials with John Deere 1070D was similar - cut-to-length method with the same bucking instructions was applied, harvesting residues were loaded into strip roads, where necessary, and accumulation mechanism of the felling head was not used. In total $78 \%$ of harvested trees were coniferous, the average volume of a tree was $0.205 \mathrm{~m}^{3}$. The only difference was removal of undergrowth trees before felling in the trials with Logset 5HP GT harvester; in case of John Deere 1070 D small trees were left growing because operators decided that removal of undergrowth is not necessary. The average productivity of John Deere $1070 \mathrm{D}$ was $14.1 \mathrm{~m}^{3} \mathrm{~h}^{-1}$, respectively, slightly higher in comparison with productivity of Logset 5HP GT $\left(13.9 \mathrm{~m}^{3} \mathrm{~h}^{-1}\right)$. Productivity of Logset 5HP GT was higher during felling of trees with diameter above 20 $\mathrm{cm}$. It can be explained with smaller time consumption for driving, because Logset 5HP GT was able to operate with maximum boom extend with larger trees, reducing thus time necessary for positioning of the machine. Productivity difference between both of is statistically insignificant at significance level $\alpha=0.05(p=0.1698)$. However, it should be taken in account, that the John Deere 1070 D trials were conducted in stands with slightly bigger diameter of trees, which might increase average productivity. In order to compare productivity of both harvesters with higher accuracy, to the comparison has to be conducted in the same stand and the same operators. When comparing time consumption for logging operations of both harvesters, it was found that John Deere 1070 D spends 3 times more time for driving in stand; respectively, John Deere $1070 \mathrm{D}$ has spent $66 \mathrm{~min} \mathrm{ha}^{-1}$ for driving in stand, but Logset 5HP GT - $19 \mathrm{~min}$, because John Deere $1070 \mathrm{D}$ required more time for positioning the machine, however loss of productivity due to additional driving was partially compensated by higher productivity during positioning of felling head, cutting and bucking operations. It was found in the study that for John Deere $1070 \mathrm{D}$ optimal distance between strip roads to avoid additional driving is $18 \mathrm{~m}$, if width of strip road is $3.5 \mathrm{~m}$. In that case all trees can be reached without leaving corridor.

Prime cost of logging and timber transportation were calculated. According to data acquired in trials, annual cost of Logset 5HP GT harvester utilized in thinning is 267 thousands $€$, from which $60 \%$ constitute variable costs, whereas annual fixed costs are around 100 thousand $€$. Calculated annual costs of log production and transportation system is 492 thousand $€$. Estimated prime cost of log production with Logset 5HP GT harvester in thinnings according to average data obtained in trials is $8.0 € \mathrm{~m}^{-3}$, but cost of the forestry system including timber transportation $-17.5 € \mathrm{~m}^{-3}$.

Table 4. Analysis of prime cost of timber production in commercial thinning

\begin{tabular}{|c|c|c|c|}
\hline Parameter & Logset 5HP harvester & Forwarder & Log truck \\
\hline \multicolumn{4}{|c|}{ Annual costs of technical units, $€$} \\
\hline Investments, $€$ & 57237 & 45269 & 17177 \\
\hline Personnel costs, $€$ & 43681 & 37922 & 16985 \\
\hline Operational costs, $€$ & 153020 & 60971 & 36085 \\
\hline Total, $€$ & 266635 & 144162 & 73759 \\
\hline \multicolumn{4}{|c|}{ Productivity } \\
\hline Stem logs with bark, $\mathrm{m}^{3} \mathrm{E} 15-\mathrm{h}^{-1}$ & 13.8 & 10.0 & 12.7 \\
\hline \multicolumn{4}{|c|}{ Timber produced annually by a technical unit } \\
\hline Production, $\mathrm{m}^{3}$ & 36884 & 30913 & 20102 \\
\hline Logs under bark, $\mathrm{m}^{3}$ & 33229 & 27849 & 18110 \\
\hline $\begin{array}{l}\text { Prime cost of logs under bark, } € \\
\mathrm{~m}^{-3}\end{array}$ & 8.02 & 5.44 & 4.07 \\
\hline
\end{tabular}


According to the study results, prime cost of $\log$ production and delivery in thinning without undergrowth extraction costs is $710 € \mathrm{ha}^{-1}$, from which costs of logging with Logset 5HP GT harvester constitute the most $325 € \mathrm{ha}^{-1}$. Timber cost depends on the average diameter of extracted trees and proportion of productive work time of the harvester, which was $87 \%$ in the trial. Extraction of small trees increases prime cost of logging. If small trees are not extracted by harvester (diameter at breast height $<8 \mathrm{~cm}$ ), prime cost of logging would reduce by $2.2 \%$; if small trees are cut down by harvester, but not delimbed and cut into logs, prime cost of logging would decrease by $2.1 \%$, respectively difference is relatively small. However, in different conditions with bigger proportion of small trees the difference could increase to a significant level.

Comparison of influence of the average diameter of extracted tree, fuel costs and fuel consumption in thinning demonstrates that the tree diameter has the biggest impact on prime cost of log production. If the average tree diameter is 14 $\mathrm{cm}$, prime cost of harvesting and delivery is $17.5 € \mathrm{~m}^{-3}$, but if the average diameter of extracted trees increases to $16 \mathrm{~cm}$, prime cost can be reduced to $14.0 € \mathrm{~m}^{-3}$. Whereas if the diameter is smaller than the average in trials, a rapid increase in prime cost of harvesting can be observed. If the average diameter of extracted tree is $8 \mathrm{~cm}$, the prime cost increases to $40 €$ $\mathrm{m}^{-3}$. Fuel price has a bigger impact on prime cost, comparing with changes in fuel consumption of the harvester observed in the trials as daily averages. The impact of fuel cost is more significant because it affects the whole supply chain.

In order to calculate ratio of expenditures and revenues, data on actual assortment structure was used according to harvester printouts. Most of produced logs are coniferous sawlogs and small dimension logs (59\%). Firewood constitutes $15 \%$ of produced material. The average timber purchase prices from 2016 were used to calculate revenue. Average diameter of extracted trees was used to find conditions, where use of the harvester is not economically viable. It was found that Logset 5HP GT with TH45 head is an economically effective solution in thinning, if the average tree diameter is at least $8 \mathrm{~cm}$. When smaller trees are harvested, ratio of expenditure and revenue becomes negative.

\section{CONCLUSIONS}

- The average productivity of Logset 5HP GT harvester in commercial thinning of coniferous stands with the average diameter of extracted trees at breast height $14 \mathrm{~cm}$ is $13.9 \mathrm{~m}^{3}$ per productive work hour. Difference in productivity between Logset 5HP GT and other middle class harvester with shorter boom length $(10 \mathrm{~m})$ in similar conditions is statistically insignificant ( $\mathrm{p}=0.1698$ ) at significance level $\alpha=0.05$.

- Prime cost of harvesting with Logset 5HP GT harvester in the study sites was $8.0 € \mathrm{~m}^{-3}$.

- Cutting of small trees (diameter at breast height $<8 \mathrm{~cm}$ ) reduced productivity by $6.9 \%$. Processing of small tress increased timber production cost by $2.1 \%$; however difference is not statistically significant. Further studies in forest stands with bigger density of small trees is necessary to evaluate impact of processing of small trees.

- According to trial results the harvester with boom length can decrease time consumption for driving in a stand by $71 \%$; however reduced driving time is partially compensated by increased time consumption for reaching trees and positioning of felling head. Additional productivity data obtained in forest stands with various densities are necessary in order to estimate influence of increased boom length and other parameters on productivity of the harvester with higher accuracy.

\section{REFERENCES}

1. Belbo, H. 2010. Comparison of two working methods for small tree harvesting with a multi tree felling head mounted on farm tractor. Silva Fennica, Vol. 44, pp. 453-464. https://doi.org/10.14214/sf.142

2. Eliasson, L., Lageson, H. 1999. Statistical yearbook of forestry 1994, Skogsstyrelsen.

3. Kalēja, S., Lazdin̄š, A., Zimelis, A., 2014. Impact of assortments's structure on harvesting productivity and costs of pre-commercial thinning. Proceedings of the International Scientific Conference: Research for rural development, Vol. 2, pp. 83-89, Latvia University of Agriculture.

4. Kärhä, K., Rönkkö, E., Gumse S-I. 2004. Productivity and Cutting Costs of Thinning Harvesters. International Journal of Forest Engineering, Vol. 15, pp.43-56.

5. Kuitto, P. J.; Keskinen, S.; Lindroos, J.; Oijala, T.; Rajamaki, J.; Rasanen, T.; Terava, J., 1994. Mechanized cutting and forest haulage. Metsatehon Tiedotus 410, pp.38.

6. Lazdiņš, A., Prindulis, U., Kalēja, S., Daugaviete, M., Zimelis, A., 2016. Productivity of Vimek 404 T5 harvester and Vimek 610 forvarder in early thinning. Agronomy Research, Vol. 14, pp. 475-484.

7. Lazdinšs, A., Zimelis, A., Kalēja, S. 2015. Production of biofuel in thinning of young stands, in first thinning and slope land cover with Moipu harvester head. Research report, Latvian State Forest Research Institute "Silava".

8. Mederski, P. S., 2006. A comparison of harvesting productivity and costs in thinning operations with and without midfield. Forest Ecology and Management, Vol. 224, pp. 286-296. https://doi.org/10.1016/j.foreco.2005.12.042

9. Moskalik, T., Borz, S. A., Dvořák, J., Ferencik, M., Glushkov, S., Muiste, P., Lazdiň̌s, A., Styranivsky, O. 2017. Timber Harvesting Methods in Eastern European Countries: a Review. Croatian Journal of Forest Engineering, Vol. 38, pp. 231-241.

10. Nurminen, T., Korpunen, H., Uusitalo, J. 2006. Time consumption analysis of the mechanized cut-to-length harvesting system. Silva Fennica 40, pp. 335. https://doi.org/10.14214/sf.346

11. Petersons, J. 2010. Factors affecting harvester productivity in forest thinning in Latvia. Proceedings of the International Scientific Conference: Research for Rural Development, Vol. 1, pp. 183-187, Latvia University of Agriculture. 
12. Pētersons, J., Drēska, A., 2014. Harvestera darba ražīgums krājas kopšanas cirtēs un izcērtamo koku vidējie stumbru tilpumi dažāda sugu sastāva audzēs. Available at http://www.silava.lv/userfiles/file/Mezzinatne\%2028961)2014/8_Petersons_Mezzinatne_28.pdf (Accessed on 27/10/2017). [In Latvian]

13. Stampfer, K., 1999: Influence of terrain conditions and thinning regimes on productivity of a track-based steep slope harvester. Proceedings of the International Mountain Logging and 10th Pacific Northwest Skyline Symposium, pp. 78-87, Oregon State University.

14. Uusitalo, J. 2010. Introduction to forest operations and technology, JVP forest systems oy.

15. von Hofsten. H., Lundström, H., Nordén, B., Thor, M. 2005. Biomass harvesting systems, analyses of seven final felling systems and four thinning systems. Research report, Skogforsk, Uppsala. 